\title{
Cardiomyopathy-hypotonia-lactic acidosis syndrome
}

INSERM

\section{Source}

INSERM. (1999). Orphanet: an online rare disease and orphan drug data base.

Cardiomyopathy-hypotonia-lactic acidosis syndrome. ORPHA:91130

Cardiomyopathy-hypotonia-lactic acidosis syndrome is characterised by hypertrophic cardiomyopathy, muscular hypotonia and the presence of lactic acidosis at birth. It has been described in two sisters (both of whom died within the first year of life) from a nonconsanguineous Turkish family. The syndrome is caused by a homozygous point mutation in the exon 3A of the SLC25A3 gene encoding a mitochondrial membrane transporter. 